\title{
BULLETIN of The BUSINESS HISTORICAL SOCIETY
}

INCORPORATED

BAKER LIBRARY, SOLDIERS FIELD, BOSTON, MASS.

Volume II, No. $3 \quad$ MAY, $1928 \quad$ Whole Number 13

\section{An Old-Time Type of Merchant}

N. S. B. Gras, Harvard University

THE recent accession of the Hancock papers to The Business Historical Society collection recalls a now forgotten type of merchant once prevailing in Europe and America. He was sometimes called the merchant prince; certainly he represents the highest class of business man from at least the thirteenth to the early nineteenth century. Sometimes he operated alone; sometimes with his brothers or cousins in the form of a family partnership.

Primarily he was a wholesaler, who imported and exported goods in considerable quantities. In the doing of this he might use supercargoes, or rely on his agents abroad. The great Italian houses of the fourteenth and fifteenth centuries, like the Fuggers of the sixteenth century, had their own agents in the chief commercial cities; while John Hancock, living in the eighteenth century, depended upon commission houses in London.

To the function of wholesaling, this merchant frequently added others which in the aggregate rivalled the chief one. He often had a retail store, and he loaned his surplus money where security and profits tempted him to do so. At times he lost, as did the Bardi and the Peruzzi when Edward III of England refused payment, thereby temporarily undermining the credit of all Florence. Moving on a little further in to the banking business, the merchant would keep the cash of his customers and of others in his own strong box. In other words he received deposits, which he came to loan along with his own funds. For friends and customers he transferred 
credit from place to place where he himself had credit. Occasionally he would join his fellows to underwrite the insurance on a ship going out to sea. Although his own ships were intended primarily to carry his own cargoes, he would sometimes rent out space to others. And his warehouse, when not fully needed for his own business, he would let others use. In these ways he was both a common carrier and a common warehouseman. Not infrequently he would take on the functions of an industrial entrepreneur, ordering ships to be built for him to be sold later, woollen cloth to be made from wool which he had purchased, and shoes from leather which he had. In this way he came to play an increasingly dominant part in the manufacturing of the time, introducing the elements of market demand, prompt supply, and labor exploitation.

As though all these were not enough, the old-time merchant often invested in lands. The Medici did so partly to extend their influence among their fellow citizens; the Fuggers for prestige and security. Robert Morris apparently thought only of the chance of gain which would come if he could own the lands which settlers would demand - all the way from New England to Georgia. But disturbances in Europe kept the settlers away and Morris went in to bankruptcy. John Hancock also invested in lands - in New England - but underwent no such losses. It is a curious fact that Morris, an excellent business man, died poor; while Hancock, an inferior merchant, died with little less wealth than he had inherited from his uncle. Doubtless the explanation is that, in his preoccupation with politics, Hancock was forced to entrust his business to subordinates to whom little or no discretion would be given in affairs. Accordingly it was probably by fortuitous circumstances that Hancock was kept out of a speculative business which by disposition he would have gladly entered - to his ruin.

But the day of this class of non-specialized merchant was nearly over. The revolutions in industry and transportation made specialization necessary. Manufacturing, transportation, banking and retailing were each to require as much capital as he had put into them all. And the large sums of capital required could best be supplied not by individual business men or family partnerships but by joint-stock corporations. 